\title{
A new Cenomanian (Late Cretaceous) coleoid (Cephalopoda) from Hâdjoula, Lebanon
}

\author{
Dirk Fuchs ${ }^{*}, 1$ and Robert Weis ${ }^{2}$ \\ ${ }^{1}$ Institut für Geologische Wissenschaften, Freie Universität Berlin, Malteser Str. 74-100, Haus D, 12249 Berlin, Germany. \\ E-mail: drig@zedat.fu-berlin.de \\ ${ }^{2}$ Musée National D’Histoire Naturelle, 25 rue Münster, 2169 Luxembourg, Luxembourg. E-mail: rweis@mnhn.lu
}

\begin{abstract}
Received 19 June 2008

Accepted 23 January 2009

Published 3 August 2009

\section{Key Words}

\section{Glyphiteuthis}

A new vampyropod coleoid from the late Cenomanian limestones of Hâdjoula (northwest Lebanon) is described. Glyphiteuthis abisaadiorum n. sp. is classified as a representative of the Trachyteuthididae, mainly on the basis of its general gladius morphology. It represents the fourth species of its genus and the second species of its genus recorded from Hâdjoula. Glyphiteuthis abisaadiorum n. sp. differs from Glyphiteuthis libanotica in having a more slender gladius. Additionally, the arms are considerably longer in Glyphiteuthis abisaadiorum n. sp. than in Glyphiteuthis libanotica.
\end{abstract}

coleoid cephalopods

Hâdjoula Limestones

gladius morphology

soft-tissue preservation

\section{Introduction}

The fossil record of cuttlefish, squid and octopus has received relatively little attention. Among malacologists, the opinion is widespread that these mainly softbodied coleoids have a poor fossil record. However, thanks to Konservat-Lagerstätten such as the Early Jurassic Posidonian Shales of Holzmaden (Germany), the Middle Jurassic La-Voulte-sur-Rhône (France) and the Late Jurassic Limestones of Solnhofen and Nusplingen, we have a comparatively precise idea about the palaeobiology of Jurassic Coleoidea. For interpretations concerning Cretaceous coleoids, in contrast, we have to rely on the Late Cretaceous Limestones of Hâqel and Hâdjoula (Lebanon), our only evolutionary window into Cretaceous times. Both outcrops are indispensable for morphological studies and phylogenetic reconstructions. It has been recently proven that the contemporary Hâqel and Hâdjoula Limestones not only compete with the Solnhofen Limestones in their state of soft-part preservation, but also in their coleoid diversity (Fuchs 2006a, 2006b, 2007; Fuchs et al. 2009).

In a re-description of trachyteuthid Glyphiteuthis $(=\mathrm{Li}$ banoteuthis) libanotica (Fraas, 1878), Fuchs (2006a) mentioned the possibility that two morphotypes of Glyphiteuthis existed in Hâqel and Hâdjoula, but could not prove this observation until additional specimens were available for comparative and quantitative analyses. A collection of coleoids from the Hâqel and Hâdjoula Limestones housed in the Musée National D'Histoire Naturelle in Luxembourg has yielded clear evidence of morphological differences. The aim of this paper is to describe a new species of Glyphiteuthis and to distinguish it from Glyphiteuthis libanotica.

\section{Geological setting}

The examined material comes from the sub-lithographical Limestones of Hâqel and Hâdjoula in north-west Lebanon. These localities are about $15 \mathrm{~km}$ apart, $45 \mathrm{~km}$ northeast of Beirut and $15 \mathrm{~km}$ east of the coastal city of Jbail (Fig. 1). Latest studies confirmed a late Cenomanian age for both Hâqel and Hâdjoula, owing to the presence of the ammonite Allocrioceras cf. annulatum (Wippich \& Lehmann 2004). Allocrioceras annulatum is a member of the lower late Cenomanian Sciponoceras gracile Zone in the Western Interior of USA and

\footnotetext{
* Corresponding author
} 


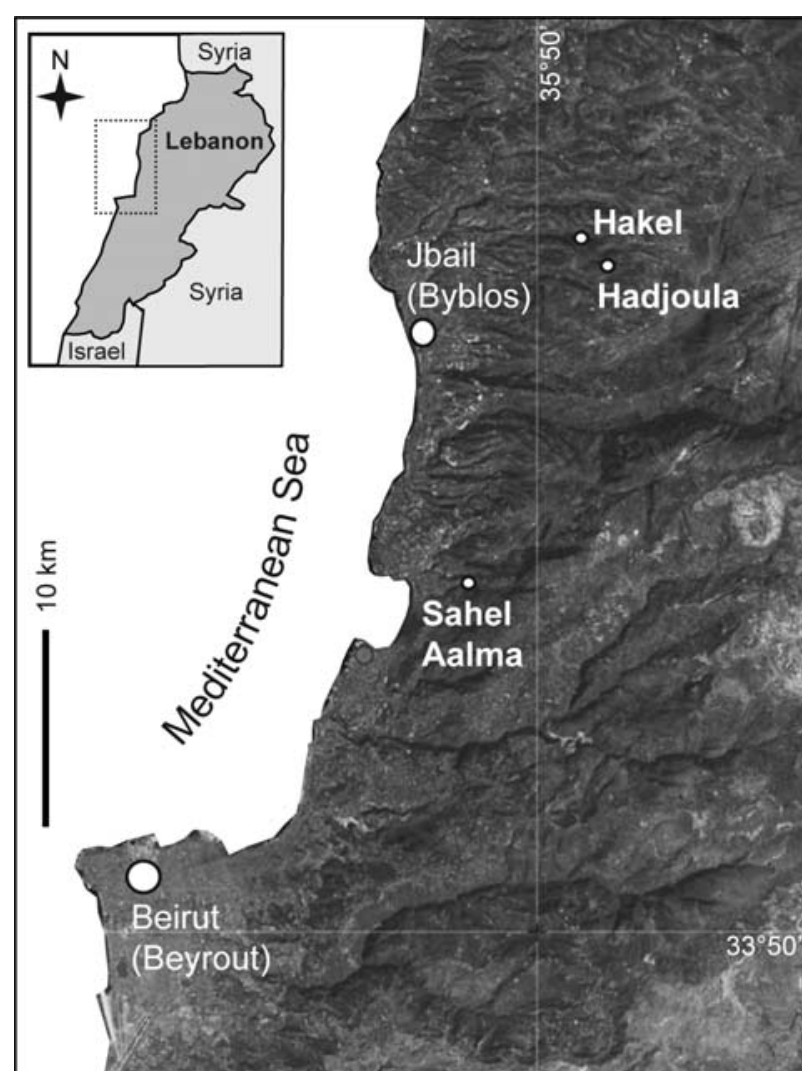

Figure 1. Topographic map of north-western Lebanon showing Hâqel and Hâdjoula in the upper right hand corner (adapted from Fuchs et al. 2009).

the Metoicoceras geslinianum Zone of the international standard.

The limestones are hard, fine-grained, well-bedded and laminated: They are often rich in fossils and have a yellowish to greyish colour (Hückel 1970, 1974; Hemleben 1977; Cappetta 1980).

During the Cenomanian, Lebanon and the whole Arabian Peninsula were part of the African platform in the northern part of the Gondwana super-continent (Philip et al. 1993). In Cenozoic times, opening of the Red Sea separated the Arabian Peninsula from Africa. Like the late Cenomanian Al-Nâmoura outcrops, Hâqel and Hâdjoula were probably deposited in small, shallow Tethyan basins with a reduced water circulation (Dalla Vecchia \& Chiappe 2002; Dalla Vecchia et al. 2002). In this scenario, mild oscillations of the relative sea level produced an exceptional sandwich of shallow water carbonate facies (Ferry et al. 2007). The described palaeoenviroment produced favourable conditions for the preservation of a rich fauna, comprising remains of fishes (Forey et al. 2003), reptiles (Dalla Vecchia et al. 2001), crustaceans (Garassino 2000), annelids (Bracchi \& Alessandrello 2005), ammonoid and coleoid cephalopods (Wippich \& Lehmann 2004; Fuchs 2006a), and others.

Although preservation of coleoid soft-parts is comparatively well-known from Konservat-Lagerstätten, the gladius remains the best-known and therefore systematically most important character complex. The gladius is a sturdy but flexible chitinous structure within the dorsal mantle of many extinct and living coleoid groups. Terminology and measurements used herein follow those of Fuchs et al. (2007: 577, fig. 1).

Institutional abbreviations. MNHNL, Musée National D'Histoire Naturelle Luxembourg; MSNM, Museo Civico di Storia Naturale di Milano; SMNS, Staatliches Museum für Naturkunde Stuttgart.

\section{Systematic palaeontology}

\author{
Subclass Coleoidea Bather, 1888 \\ Superorder Vampyropoda Boletzky, 1992 \\ Order Octobrachia Fioroni, 1981
}

\section{Suborder Teudopseina Starobogatov, 1983}

Diagnosis. Gladius with clearly reduced and opened conus (spoonshaped conus). Lateral fields and hyperbolar zones less than half of the gladius length. Hyperbolar zones between lateral and median field as well-developed broad furrows. Anterior median field rounded or pointed.

Families included. Trachyteuthididae Naef, 1921; Teudopseidae Regteren Altena, 1949; Palaeololiginidae Naef, 1921; Muensterellidae Roger, 1952.

Remarks. The systematic position of the Teudopseina is controversial. The pros and cons for placing teudopseid families within the Vampyropoda are extensively discussed by Fuchs et al. (2007a: 577).

\section{Family Trachyteuthididae Naef, 1921}

Type genus. Trachyteuthis Meyer, 1846; type species Trachyteuthis ensiformis Meyer, 1846; Tithonian (Late Jurassic), Solnhofen region, Southern Germany.

Diagnosis. Gladius with granules (tubercles) on the dorsal surface.

Genera included. Trachyteuthis Meyer, 1846; Glyphiteuthis Reuss, 1854; Actinosepia Whiteaves, 1897.

Stratigraphic and geographic range. Middle Jurassic (Callovian) Late Cretaceous (Maastrichtian); Europe, Central Russia, Lebanon, Cuba, Chile, Antarctica, Australia and North America (see Fuchs et al. (2007a) and Fuchs \& Schultze (2007) for more details).

\section{Glyphiteuthis Reuss, 1854}

(junior syn. Libanoteuthis Kretzoi, 1942)

Type species. Glyphiteuthis ornata Reuss, 1854

Diagnosis. Gladius with hyperbolar zone length / gladius length ratio of $0.38-0.39$. Anterior median field sharply pointed and with a prominent mid-dorsal keel. Angle of diverging inner asymptotes $30^{\circ}$ or less.

Stratigraphic and geographic range. Cenomanian (Lebanon and France), early/middle Turonian (Czech Republic), ?late Santonian (Lebanon).

Species included. Glyphiteuthis ornata (= minor?) Reuss, 1854 early / middle Turonian Bílá Hora Formation (Czech Republic), G. libanotica (Fraas, 1878), G. abisaadiorum n. sp., late Cenomanian of Hâqel and Hâdjoula (Lebanon), and G. boutillieri (Lennier, 1866) early Cenomanian of Normandy (France).

Remarks. For a long time, "Geoteuthis" libanotica Fraas, 1878 from the Cenomanian of Hâqel was com- 
monly assigned to the genus Trachyteuthis. Kretzoi (1942) first recognised differences from Trachyteuthis hastiformis and subsequently established a new genus, Libanoteuthis. Kretzoi (1942) did not find significant similarities of "Libanoteuthis" libanotica and Glyphiteuthis ornata. Fuchs (2006a) therefore regarded Libanoteuthis as a junior synonym of Glyphiteuthis.

\section{Glyphiteuthis abisaadiorum n. sp.}

Figure 2

2006 Glyphiteuthis libanotica Fraas, 1878. - Fuchs: 12, pl. 9, fig. B-C.

Derivation of name. The name is in honour of the family Abi-Saad, the owner of the Hâqel quarry and tenant of the Hâdjoula quarry.

Diagnosis. Gladius slender with hyperbolar zone length/ gladius length ratio of 0.39 . Angle of diverging inner asymptotes $23^{\circ}$. Arms at least 1.5 times longer than the gladius.

Holotype. CRE42a $+\mathrm{b}$, deposited in the Musée National D'Histoire Naturelle de Luxembourg.

Paratype. CRE43, deposited in the Musée National D'Histoire Naturelle de Luxembourg.

Type locality. Hâdjoula $\left(34^{\circ} 07^{\prime} 56.70^{\prime \prime} \mathrm{N} ; 35^{\circ} 44^{\prime} 41.60^{\prime \prime} \mathrm{E}\right)$, Lebanon

Formation and age. Metoicoceras geslinianum Zone (international standard; corresponds to Sciponoceras gracile Zone in Western Interior); early late Cenomanian.

Description. The holotype, which consists of slab and counter slab, has a preserved length of $230 \mathrm{~mm}$ (Figs 2A-C). It shows an extraordinary well-preserved gladius and remnants of mantle musculature, eye capsules, buccal mass, and arm musculature.

On the slab, the gladius is seen in dorsal aspect; on the counter slab as imprints of the external surface of the dorsal side. It is $84 \mathrm{~mm}$ in total length and shows only a slight dorsoventral compaction. The posterior half and the most anterior part of the gladius is preserved on the slab. The middle parts are dissolved, but preserved as imprints. Based on distinct growth increments, the gladius can be subdivided into a median field, a pair of comparatively wide and long hyperbolar zones, and a pair of lateral fields (Fig. 2C). The anteriorly sharply pointed median field exhibits an inconspicuous, but distinct mid-dorsal keel as well as very fine granules. The granulated area diverges at an angle of c. $10^{\circ}$. The maximum length of the hyperbolar zone $(32 \mathrm{~mm})$ is well-defined through the inner asymptotes. Hyperbolar growth lines are weakly curved. Inner asymptotes open at an angle of $23^{\circ}$; outer asymptotes at $40^{\circ}$. The parabolar lateral fields are $25 \mathrm{~mm}$ long. Maximum width of the gladius is $22 \mathrm{~mm}$. Gladius width measured at the anterior end of the hyperbolar zones is $16 \mathrm{~mm}$. After $50 \%$ of the total gladius length, the gladius width measures $14 \mathrm{~mm}$.

The mantle outline is easily perceptible owing to preservation of musculature (Fig. 2B). Mantle musculature must be atrophied post-mortem because the mantle length is shorter than the gladius $(74 \mathrm{~mm})$. Up to the anterior lateral field end, the gladius tightly fits the entire mantle outline. From this part forwards, the mantle width is larger than the gladius width. The anterior mantle margin is $28 \mathrm{~mm}$ wide. A pair of oval reddishbrown discolorations anterior to the mantle margin can be interpreted as eye capsules, i.e. lateral remnants of the cephalic cartilage (Fig. 2A). Each is $16 \mathrm{~mm}$ long and $10 \mathrm{~mm}$ wide.

White circular remnants of the buccal mass are visible between the eye capsules and the arm bases (Fig. 2A). Beaks are not preserved. Although the arms are incompletely preserved, the counter slab exhibits an arm length of at least $125 \mathrm{~mm}$ (Fig. 2A). Only a few millimetres of the anterior arm tips appear to be missing. The ratio arm length/gladius length is therefore larger than 1.47. The number of arms cannot be determined. Either suckers or cirri are visible. Fins are not preserved.

Similar to the holotype, the paratype preserves a slightly compacted gladius (60 mm length; Figs 2DF). The dorsoventrally embedded gladius clearly displays the roof-shaped anteriorly pointed median field; it is furnished with a prominent keel on its top (Fig. 2F). Characteristic granules are poorly visible. They are most likely eroded. The gladius width is $16 \mathrm{~mm}$ at its maximum extension, $10 \mathrm{~mm}$ at the anterior end of the hyperbolar zones, and $9 \mathrm{~mm}$ half way along the total gladius length. Inner asymptotes diverge at an angle of $23^{\circ}$; the outer asymptotes at $41^{\circ}$. The hyperbolar zones are $20 \mathrm{~mm}$ in length; the lateral fields $16 \mathrm{~mm}$.

The ink sac lies beside the gladius indicating that the dead animal was slightly distorted during embedding. Preservation of arms is incomplete, but they are at least $52 \mathrm{~mm}$ long.

Additional specimens that can be determined as G. abisaadiorum n. sp. are housed in the Museo Civico di Storia naturale Milano. Specimen MSNMi24801 originates from Hâdjoula, whereas specimens MSNMi 20587 and MSNMi12599 come from Hâqel. Although specimen MSNMi24801 (Fig. 2G) is laterally embedded, it can be determined as G. abisaadiorum n. sp. on the basis of its obviously long arms.

Comparisons. Granules on the dorsal gladius surface unambiguously identify present specimens as a trachyteuthid gladius (Fuchs et al. 2007a). The genus Teudopsis (Fig. 3A), which exhibits a gladius similar to trachyteuthids, lacks this granulation. In general, gladius indices differ only slightly in Trachyteuthis and Glyphiteuthis (Tab. 1). Particularly width-length ratios have to be interpreted with care owing to the rate and level of compaction.

Trachyteuthis exhibits a rounded or only weakly pointed anterior gladius end whereas Glyphiteuthis shows a sharply pointed anterior gladius end (Figs 3BE). In Actinosepia, the anterior gladius end is serrated (Fig. 3F). Furthermore, the median field in Glyphiteuthis is distinctly roof-shaped in cross-section with a prominent keel on its top. In contrast, the median field is smoothly curved in Trachyteuthis and Actinosepia. 
Within the genus Glyphiteuthis, gladii differ in width (Figs 2, 3C-E, 4A-E, Tab. 1). The gladius width/ gladius length ratio $(\mathrm{GW} / \mathrm{GL})$ is smallest in G. abisaadio- rum n. sp., followed by G. libanotica. The gladius of $G$. ornata appears to be the widest (in the single specimen of G. boutillieri, the gladius is incomplete). Differ-
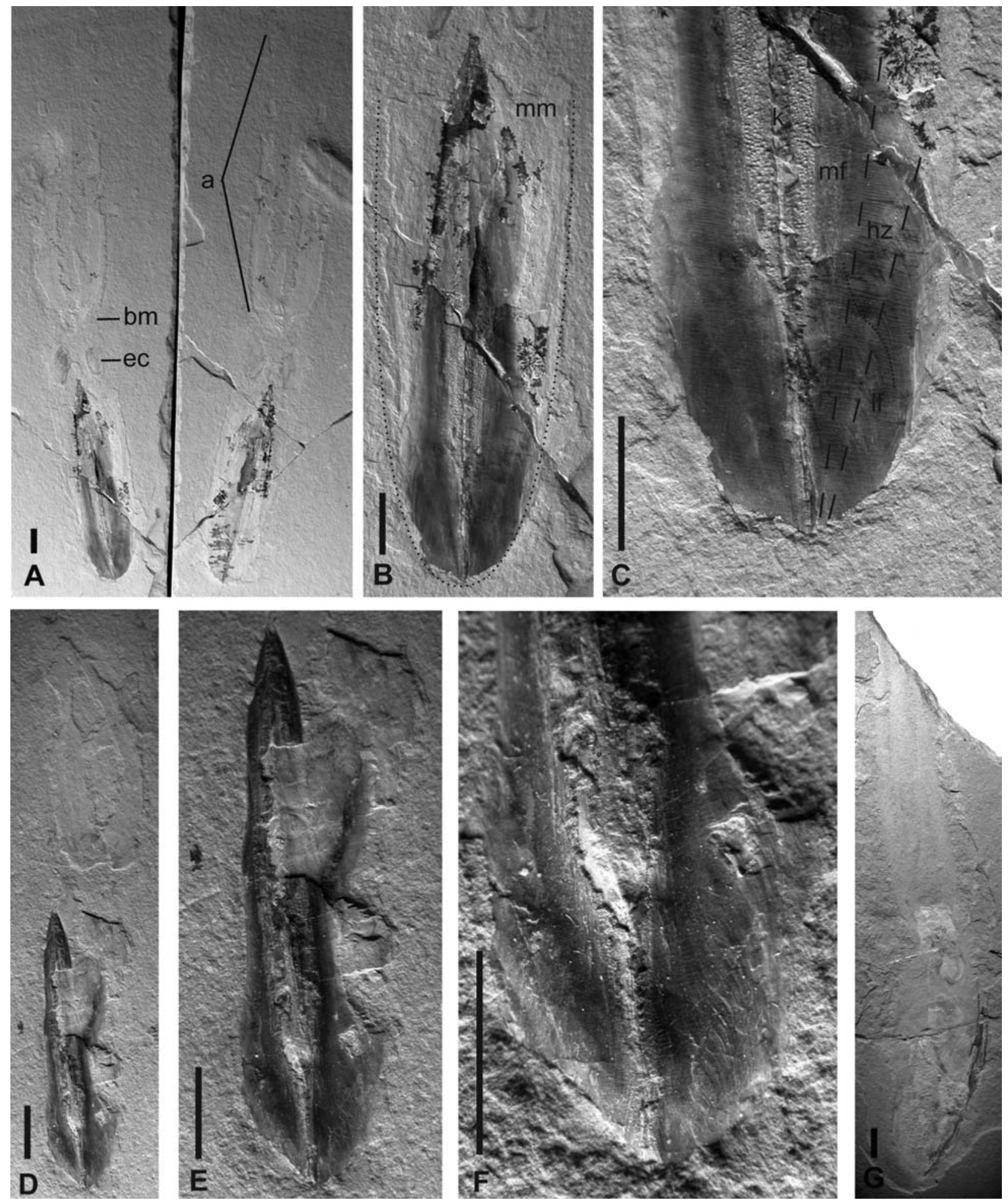

Figure 2. Glyphiteuthis abisaadiorum n. sp., from the Upper Cenomanian of Hâdjoula, Lebanon. A-C. Holotype (CRE042). DF. Paratype (CRE043). A. Slab and counter slab in dorsal view ; scale bar $=10 \mathrm{~mm}$. B. Close-up of A to show the gladius; scale bar $=10 \mathrm{~mm}$. C. Close-up of B to show details of the posterior gladius; scale bar $=10 \mathrm{~mm}$. D. Dorsal overview; scale bar $=10 \mathrm{~mm}$. E. Close-up of D to show the gladius; scale bar $=10 \mathrm{~mm}$. F. Close-up of $\mathrm{E}$ to show details of the posterior gladius; scale bar $=$ $10 \mathrm{~mm}$. G. Specimen MSNMi24801 seen in lateral view to demonstrate the enormous arm length; scale bar $=10 \mathrm{~mm}$. Abbreviations: $\mathbf{a}$ - arms; $\mathbf{b}$ - beak; bm - buccal mass; ec - eye capsule; hz - hyperbolar zone; ia - inner asymptote; lf - lateral field; $\mathbf{m f}$ - median field; mm - muscular mantle; dashed lines - inner and outer asymptotes. 
Table 1. Comparison of morphometric indices and some other gladius characters between Trachyteuthis, Glyphiteuthis abisaadiorum n. sp., G. libanotica, G. ornata and G. boutilierei.

\begin{tabular}{|c|c|c|c|c|c|}
\hline & Trachyteuthis & G. abisaadiorum n. sp. & G. libanotica & G. ornata & G. boutillieri \\
\hline $\begin{array}{l}\text { hyperbolar zone length/ } \\
\text { gladius length (HzL/GL) }\end{array}$ & $0.36-0.42$ & 0.38 & 0.39 & 0.38 & $?$ \\
\hline $\begin{array}{l}\text { lateral field length/ } \\
\text { gladius length (LFL/GL) }\end{array}$ & $0.32-0.35$ & 0.30 & 0.33 & 0.31 & $?$ \\
\hline $\begin{array}{l}\text { gladius width at half way along } \\
\text { of gladius length/ } \\
\text { gladius length (GW1/2gl/GL) }\end{array}$ & 0.27 & 0.16 & 0.20 & 0.20 & $?$ \\
\hline $\begin{array}{l}\text { gladius width at anterior end } \\
\text { of hyperbolar zone/ } \\
\text { gladius length (GWhz/GL) }\end{array}$ & 0.27 & 0.19 & 0.23 & 0.24 & $?$ \\
\hline $\begin{array}{l}\text { maximum gladius width/ } \\
\text { gladius length (GWmax/GL) }\end{array}$ & $0.35-0.39$ & 0.26 & 0.32 & 0.38 & $?$ \\
\hline $\begin{array}{l}\text { angle of diverging } \\
\text { inner asymptotes ( } \mathrm{Aia} \text { ) }\end{array}$ & $40-43^{\circ}$ & $23^{\circ}$ & $28^{\circ}$ & $30^{\circ}$ & $?$ \\
\hline $\begin{array}{l}\text { angle of diverging granulated } \\
\text { area (Aga) }\end{array}$ & $\begin{array}{l}\text { large to restricted } \\
\text { to keel }\end{array}$ & c. $10^{\circ}$ & c. $17^{\circ}$ & c. $8^{\circ}$ & $?$ \\
\hline $\begin{array}{l}\text { arm length/gladius length } \\
(\mathrm{AL} / \mathrm{GL})\end{array}$ & I & $>1.47$ & 0.44 & $?$ & $?$ \\
\hline anterior gladius shape & $\begin{array}{l}\text { rounded - weakly } \\
\text { pointed }\end{array}$ & sharply pointed & sharply pointed & sharply pointed & sharply pointed \\
\hline
\end{tabular}

ences in width are additionally expressed by the apical angle (angle of diverging inner asymptotes). Moreover, a slight constriction of the anterior median field present in G. libanotica and G. ornata is absent in G. abisaadiorum n. sp. Finally, G. abisaadiorum n. sp. possesses arms that are almost 1.5 times longer than the gladius length. In contrast, arms are considerably shorter than the gladius in G. libanotica. In G. ornata and G. boutillieri, the latter feature is still unknown.

In general, the gladius of G. abisaadiorum n. sp. also resembles the palaeololiginid Rachiteuthis donovani Fuchs, 2006a from Hâdjoula (rachis-like median field, pointed anterior gladius end, keel). This is only superficial, as $R$.donovani unambiguously lacks the dorsal granulation.

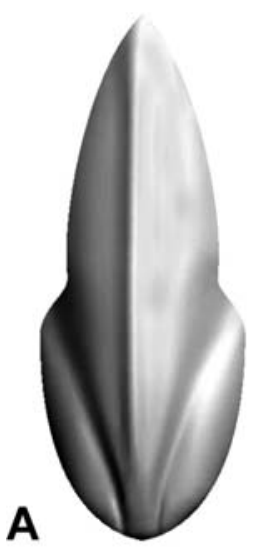

B

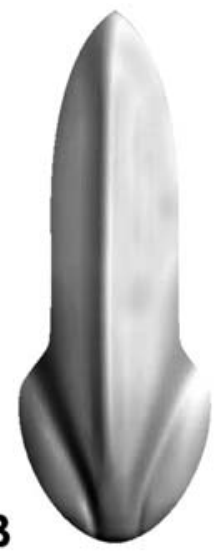

Discussion. Fuchs (2006a: 13) suggested that two morphotypes of Glyphiteuthis possibly co-occur in Hâqel. Present observations clearly support this assumption: G. abisaadiorum n. sp. is identical with the "slender form" mentioned in Fuchs (2006a) and G. libanotica typifies the "stouter form". Fuchs (2006a) further presumed that arm length is a second character that distinguishes these two forms. The collection of the Musée National D'Histoire Naturelle Luxembourg confirms this observation. The slender gladius of G. abisaadiorum n. sp. is associated with arms that are considerably longer than the gladius, while G. libanotica is characterised by arms that are shorter than the gladius.

Both G. abisaadiorum n. sp. and G. libanotica occur in Hâqel and Hâdjoula. Trachyteuthis sp. was reported
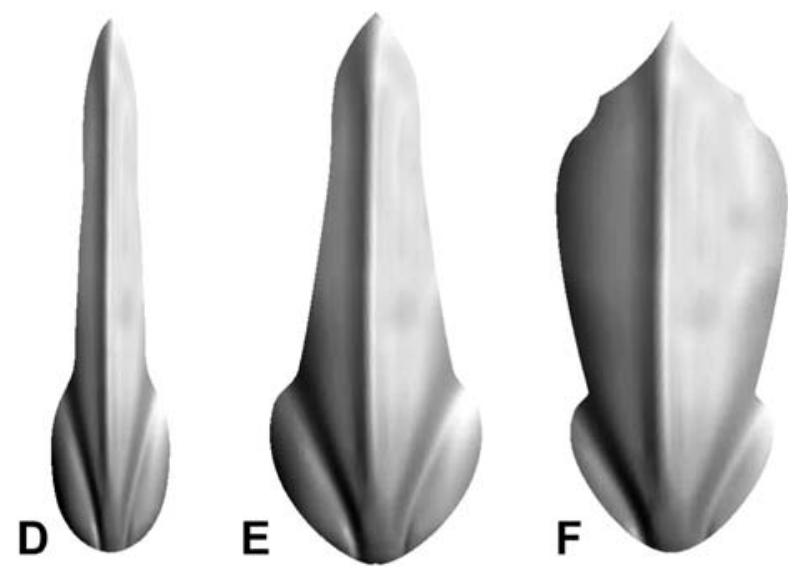

Figure 3. Comparison of gladius shape of teudopseid vampyropods. A. Teudopsis subcostata (Toarcian). B. Trachyteuthis teudopsiformis (Tithonian). C. Glyphiteuthis libanotica (Cenomanian). D. Glyphiteuthis abisaadiorum n. sp. (Cenomanian). E. Glyphiteuthis ornata (Turonian). F. Actinosepia canadensis (Maastrichtian). 

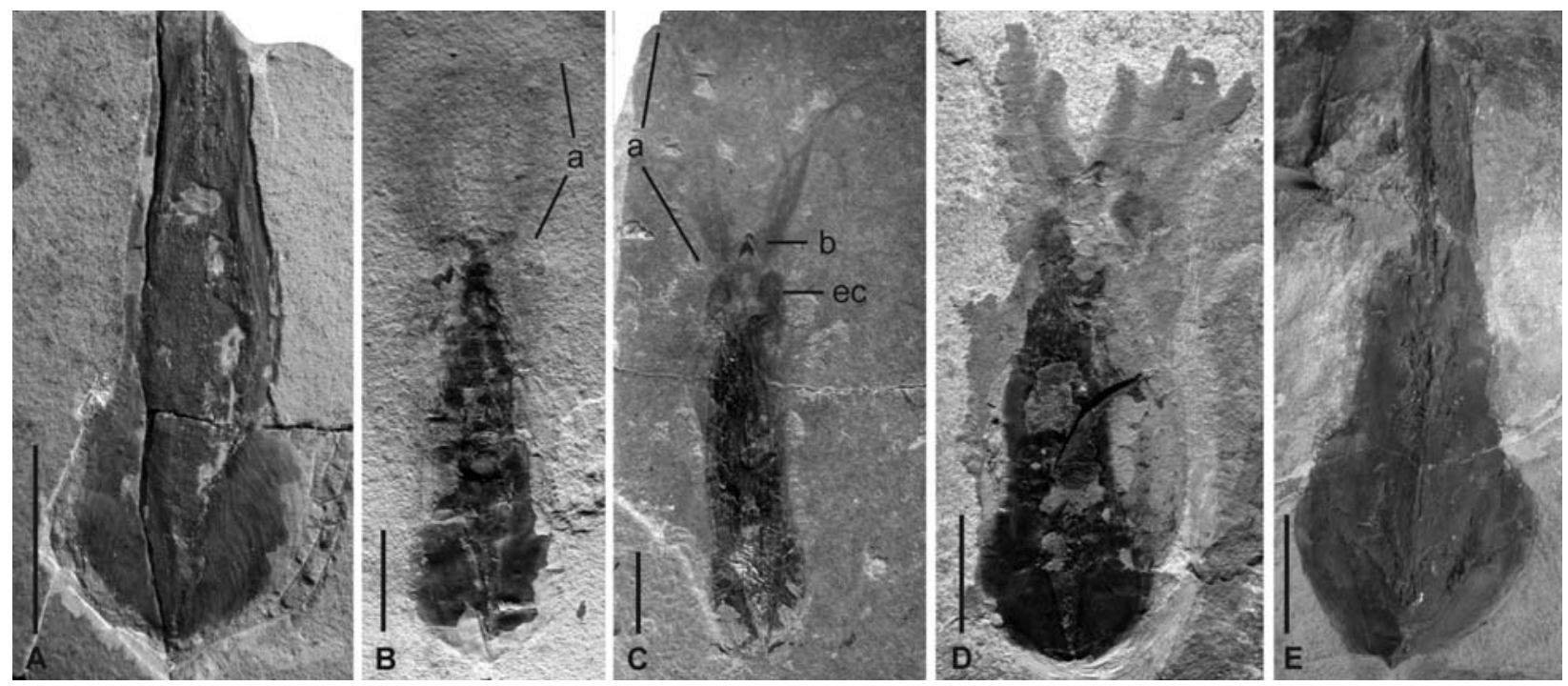

Figure 4. A-D. Glyphiteuthis libanotica (Woodward, 1883) from the Upper Cenomanian of Hâqel and Hâdjoula. A. Holotype (SMNS 26269) (Hâqel); scale bar $=10 \mathrm{~mm}$. B. Specimen CRE041 (Hâqel); scale bar $=10 \mathrm{~mm}$. C. Specimen CRE034 (Hâdjoula); scale bar $=10 \mathrm{~mm}$. D. Specimen MSNMi25138 (Hâqel); scale bar $=10 \mathrm{~mm}$. E. Glyphiteuthis ornata Reuss, 1854 (Bohemia); scale bar $=10 \mathrm{~mm}$. Abbreviations as in Figure 2 .

from Hâqel, but not from Hâdjoula (Fuchs 2006a). Although Al-Nâmoura is very close to Hâqel and Hâdjoula and considered to be only slightly older, coleoids are still unknown from Al-Nâmoura. The question if this distributional pattern of trachyteuthids is real or a collecting artefact must remain open until new material appears.

So far, G. abisaadiorum n. sp. is the most slender member of the trachyteuthids (Figs 3B-F). Fuchs et al. (2007a: 587) regarded Tr. teudopsiformis from the Tithonian Solnhofen Limestones to be the connecting link between the Early Jurassic genus Teudopsis, the Middle Jurassic-Late Cretaceous genus Trachyteuthis, and the Late Cretaceous genus Glyphiteuthis. Tr. teudopsiformis possesses a mosaic of characters that is shared by Teudopsis, Trachyteuthis, and Glyphiteuthis (e.g. mid-dorsal keel, comparatively narrow granulated area, pointed anterior gladius end). Morphologically and phylogenetically, Tr. teudopsiformis is very close to G. libanotica and G. ornata. G. abisaadiorum n. sp. most likely represents a side branch in the trachyteuthid lineage, owing to its slender gladius.

\section{Conclusions}

The present study shows that vampyropod coleoids and particularly trachyteuthids were much more diversified than previously thought and that phylogenetically very close taxa co-existed in time and space (Fuchs et al. 2007a, 2007b; Fuchs \& Schultze 2007). Superficial similarities between trachyteuthid Glyphiteuthis abisaadiorum sp. n. and paleololiginid Rachiteuthis donovani further demonstrates a comparatively high amount of convergent developments within coleoid gladii. Gladius morphology is still the most important character to dis- tinguish vampyropod taxa. The present study also shows that our morphological knowledge is continuously increasing and that soft-tissue characters such as arm length are useful systematic features as well.

\section{Acknowledgements}

Owing to the commitment of George Bechet and Alain Faber (both Luxembourg-City, Luxembourg), the Musée National D'Histoire Naturelle Luxemburg was able to purchase the studied material. We are grateful to Anne Beck (Berlin, Germany), who kindly reviewed the English language. We thank furthermore Larisa Doguzhaeva (Moscow, Russia) and Patricia Weaver (Raleigh, USA) for their thorough reviews and critical comments.

\section{References}

Bather, F. A. 1888. Shell growth in Cephalopoda (Siphonopoda). - The Annals and Magazine of Natural History 6: 421-427.

Boletzky, S. v. 1992. Evolutionary aspects of development, life style, and reproduction mode in incirrate octopods (Mollusca, Cephalopoda). - Revue Suisse Zoologie 4: 755-770.

Bracchi, G. \& Alessandrello, A. 2005. Paleodiversity of the free-living polychaetes (Annelida, Polychaeta) and description of the new taxa from the Upper Cretaceous Lagerstaetten of Haqel, Hadjoula and Al-Namoura (Lebanon). - Memorie Società Italiana di Scienze Naturali, Museo di Storia Naturale Milano 32 (3): $1-64$.

Cappetta, H. 1980. Les Selachiens du Cretace Superieur du Leban. I: Requins. - Palaeontographica A 168(1-4): 69-148.

Dalla Vecchia, F. M. \& Chiappe, L. M. 2002. First avian skeleton from the Mesozoic of northern Godwana. - Journal of Vertebrate Paleontology 22 (4): 856-860.

Dalla Vecchia, F. M., Arduini, P. \& Kellner, A. W. A. 2001 The first pterosaur from the Cenomanian (Late Cretaceous) Lagerstatten of Lebanon. - Cretaceous Research 22: 219-225.

Dalla Vecchia, F. M., Venturini, S. \& Tentor, M. 2002. The Cenomanian (Late Cretaceous) Konservat-Lagerstätte of en Nammoura 
(Kesrouane Province), northern Lebanon. - Bolletino della Societa Paleontologica Italiana 41 (1): 51-68.

Ferry, S., Merran, Y., Grosheny, D. \& Mroueh, M. 2007. The Cretaceous of Lebanon in the Middle East (Levant) context. - Carnets de Géologie, Mémoir 2007/2 Abstract 08, Maintenon: 38-42.

Fioroni, P. 1981. Die Sonderstellung der Sepioliden, ein Vergleich der Ordnungen der rezenten Cephalopoden. - Zoologische Jahrbücher, Systematik 108: 178-28.

Forey, P. L., Yi, L., Patterson, C. \& Davies, C. E. 2003. Fossil fishes from the Cenomanian (Upper Cretaceous) of Namoura, Lebanon. Journal of Systematic Palaeontology 1 (4): 227-330.

Fraas, O. 1878. Geologisches aus dem Libanon. - Jahreshefte des Vereins für vaterländische Naturkunde in Württemberg 34: 257-391.

Fuchs, D. 2006a. Diversity, Taxonomy and Morphology of vampyropod Coleoids (Cephalopoda) from the Upper Cretaceous of Lebanon. - Memorie Società Italiana di Scienze Naturali, Museo di Storia Naturale Milano 34 (II): 1-28.

Fuchs, D. 2006b. Fossil erhaltungsfähige Merkmalskomplexe der Coleoidea (Cephalopoda) und ihre phylogenetische Bedeutung. Berliner Paläobiologische Abhandlungen 8: 1-115.

Fuchs, D. 2007. Coleoid Cephalopods from the Plattenkalks of the Late Jurassic of Southern Germany and the Late Cretaceous of Lebanon - A faunal comparison. - Neues Jahrbuch für Geologie und Paläontologie 245 (1): 59-69.

Fuchs, D., Bracchi, G., \& Weis, R. (2009). New records of octopods (Cephalopoda: Coleoidea) from the Late Cretaceous (Upper Cenomanian) of Hâqel and Hâdjoula (Lebanon). - Palaeontology 52 (1): $65-81$

Fuchs, D., Engeser, T., \& Keupp, H. 2007a. Gladius shape variation in the genus Trachyteuthis Meyer, 1846 (Cephalopoda: Coleoidea) from the Late Jurassic Plattenkalks of Nusplingen (Kimmeridgian) and Solnhofen (Tithonian). - Acta Palaeontologica Polonica 52 (3): $575-589$.

Fuchs, D., Klinghammer, A. \& Keupp, H. 2007b. Taxonomy, morphology and phylogeny of plesioteuthidid coleoids from the Upper Jurassic (Tithonian) Plattenkalks of Solnhofen. - Neues Jahrbuch für Geologie und Paläontologie 245 (2): 239-252.

Fuchs, D. \& Schultze, H.-P. 2007. Trachyteuthis covacevichi n. sp., a Late Jurassic coleoid cephalopod from the Paleopacific. - Fossil Record 11 (1): 39-49.

Garassino, A. 2000. New decapod crustaceans from the Cenomanian (Upper Cretaceous) of Lebanon. - Atti della Società italiana di scienze naturali e del museo civico di storia naturale di Milano 141 (2): $237-250$.

Hemleben, C. 1977. Rote Tiden und die oberkretazischen Plattenkalke im Libanon. - Neues Jahrbuch für Geologie und Paläontologie Monatshefte 1977 (4): 239-255.
Hückel, U. 1970. Die Fischschiefer von Haquel und Hajoula in der Oberkreide des Libanon. - Neues Jahrbuch für Geologie und Paläontologie Abhandlungen 135 (2): 113-149.

Hückel, U. 1974. Vergleich des Mineralbestandes der Plattenkalke Solnhofens und des Libanon mit anderen Plattenkalken. - Neues Jahrbuch für Geologie und Paläontologie Abhandlungen 145 (2): 153-182.

Kretzoi, M. 1942. Necroteuthis n. gen. (Ceph. Dibr. Necroteuthidae n. f.) aus dem Oligozän von Budapest und das System der Dibranchiata. - Földtani Közlöny 72: 124-138.

Lennier, G. 1886. Notes pour servir à l'étude de la paléontologie normande. - Bulletin de la Société de Géologie de Normandie 11: $21-31$.

Meyer, H. v. 1846. Mitteilungen an Prof. Bronn gerichtet. - Neues Jahrbuch Mineralogischer, Geognostischer und Geologischer Petrefactenkunde 1846: 596-599.

Naef, A. 1921. Das System der dibranchiaten Cephalopoden und die mediterranen Arten derselben. - Mitteilungen aus der zoologischen Station zu Neapel 22: 527-542.

Philip, J., Babinot, J.-F., Tronchetti, G., Fourcade, E., Ricou, L. E., Guiaud, R., Bellion, Y., Herbin, J.-P., Combes, P.-E., Conee, J.-J. \& Dercourt, J. 1993. Late Cenomanian Palaeoenvironments (94 to 92 Ma). In Dercourt, J., Ricou, L.-E. \& Vrielynck, B. (eds). Atlas Tethys Palaeoenvironmental maps. Gauthier-Villars, Paris: pp. 153-178.

Regteren Altena, C. O. van 1949. Teyleŕs Museum systematic catalogue of the palaeontological collection - sixth supplement (Teuthoidea). - Archives du Musée Teyler 3 (10): 53-62.

Reuss, A. E. 1854. Loliginidenreste in der Kreideformation. - Abhandlungen der königlichen böhmischen Gesellschaft für Wissenschaften 5 (8): 29-32.

Roger, J. 1952. Sous-classes des Dibranchiata Owen, 1836. In Piveteau, J. (ed.). Traité de Paléontologie. Masson, Paris: pp. 689755.

Starobogatov, Y. I. 1983. The System of the Cephalopoda. In Starobogatov, Y. I. \& Nesis, K. N., (eds). Taxonomy and ecology of Cephalopoda. Zoological Institute, USSR Academy of Sciences, Leningrad: pp. 4-7.

Whiteaves, J. F. 1897. Some remains of a sepia-like Cuttlefish from the cretaceous rocks of the South Saskatchewan. - The Canadian Record of Science VII: 459-462.

Wippich, G. E. \& Lehmann, J. 2004. Allocrioceras from the Cenomanian (mid-Cretaceous) of the Lebanon and its bearing on the palaeobiological interpretation of heteromorphic ammonites. Palaeontology 47 (5): 1093-1109.

Woodward, H. 1883. On a new genus of fossil "Calamary" from the Cretaceous formation of Sahel Alma, near Beirut, Lebanon, Syria. Geological Magazine, new series 10: 1-5. 